\title{
Penerapan Model Pembelajaran Drill terhadap Aktivitas dan Hasil Belajar Siswa Kelas X Desain Grafika 1 Di SMK Negeri 4 Gowa
}

\author{
The Implementation of Drill Learning Model to the Chemistry Student's Activity \\ and Achievement of the Graphic Design 1 Class X of SMK Negeri 4 Gowa
}

\author{
Zaenab \\ SMK Negeri 4 Gowa
}

\begin{abstract}
ABSTRAK
Penelitian ini bertujuan untuk mengetahui hasil belajar peserta didik pada mata pelajaran kimia kelas X Desain Grafika 1 SMK Negeri 4 Gowa Tahun pelajaran 2018/2019 yang diajar dengan menggunakan model pembelajaran Drill, pada pokok bahasan Struktur Atom dan Sistem Periodik. Jenis penelitian yang digunakan dalam penelitian ini adalah PTK (Penelitian Tindakan Kelas). Subjek dalam penelitian ini adalah Peserta didik Kelas X Desain Grafika 1 SMK Negeri 4 Gowa yang berjumlah 35 orang. Instrumen penelitian yang digunakan dalam pengumpulan data adalah tes hasil belajar kimia setiap akhir siklus, pedoman angket dan pedoman observasi. Teknik analisis data yang digunakan adalah analisis deskriptif kualitatif dan analisis deskriptif kuantitatif. Hasil penelitian menunjukkan rata-rata hasil belajar kimia Peserta didik kelas X Desain Grafika 1 SMK Negeri 4 Gowa yang mengikuti mata pelajaran dengan penerapan model pembelajaran Drill pada siklus I adalah ketuntasan belajar $71,43 \%$, selanjutnya rata-rata hasil belajar kimia Peserta didik pada siklus II adalah 77,15\% dengan ketuntasan belajar $100 \%$. Jadi dapat disimpulkan bahwa penerapan model pembelajaran Drill ini dapat meningkatkan hasil belajar peserta didik pada mata pelajaran kimia kelas X Desain Grafika 1 SMK Negeri 4 Gowa.
\end{abstract}

Kata kunci: Model Drill, Hasil belajar

\begin{abstract}
This study aims to determine student learning outcomes in chemistry subjects of Graphic Design 1 class X of Vocational School 4 Gowa in the 2018/2019 academic year taught using the Drill learning model, on the subject of Atomic Structures and Periodic Systems. This type of research used in this study is Classroom Action Research. The subjects in this study were students of Graphic Design 1 Class X of Vocational School 4 Gowa with a total of 35 people. The research instruments used in data collection were chemistry learning achievement tests at the end of each cycle, questionnaire guidelines, and observation guidelines. The data analysis technique used is qualitative descriptive analysis and quantitative descriptive analysis. The results showed the
\end{abstract}


average chemistry learning outcomes of Graphic Design 1 Class $\mathrm{X}$ students of Vocational School 4 Gowa by application of the Drill learning model in the first cycle were mastery learning $71.43 \%$ and at second cycle was $77.15 \%$ with $100 \%$ mastery learning. So it can be concluded that the application of this Drill learning model can improve student learning outcomes in chemistry subjects Graphic Design 1 Class X of Vocational School 4 Gowa.

Keywords: Drill Method, Student's Achievement

\section{PENDAHULUAN}

SMK Negeri 4 Gowa merupakan salah satu sekolah yang telah menerapkan sistem pembelajaran berbasis kompetensi dengan standar ketuntasan untuk mata pelajaran kimia adalah $75 \%$. Berdasarkan hasil observasi dan wawancara terhadap guru mata pelajaran kimia, diperoleh keterangan bahwa pada tahun ajaran 2017-2018 ketuntasan untuk materi struktur atom dan sistem periodik hanya mencapai $55 \%$ dan setelah dilakukan remedial, ketuntasannya mencapai $68 \%$. Pada materi struktur atom dan sistem periodik siswa membutuhkan kecakapan mental, misalnya: menghafal, menjumlah, mengkalikan dan membagi. Selain itu, siswa juga sudah harus mampu mengintegrasikannya dengan meterimateri lain khususnya tentang stoikimetri.

Usaha meningkatkan aktivitas dan hasil belajar siswa merupakan hal yang tidaklah mudah. Salah satu cara untuk meningkatkan aktivitas dan hasil belajar siswa adalah dengan memilih model yang tepat, sedangkan penerapan model pembelajaran yang tidak tepat dapat menurunkan motivasi dan minat belajar siswa sehingga tujuan pembelajaran tidak tercapai secara optimal.
Salah satu cara yang perlu dilakukan untuk menanggulangi rendahnya hasil belajar siswa tersebut adalah menggunakan model pembelajaran yang sesuai dengan materi yang akan diajarkan dan lebih menjadikan siswa sebagai pusat pembelajaran. Salah satu model pembelajaran yang dipandang mampu mengaktifkan dan meningkatkan hasil belajar siswa adalah model drill atau latihan (Ramlah, 2018). Model drill dipandang mampu meningkatkan kemampuan siswa sebagaimana dikemukakan oleh Hillgar dan Bower dalam Muhibbin Syah (2004), bahwa semakin sering suatu perilaku dilatih atau digunakan maka semakin mantap eksistensi perilaku tersebut.

Sehubungan dengan hal tersebut di atas, maka dalam penelitian tindakan kelas ini menerapkan langkah-langkah model pembelajaran Drill untuk dapat meningkatkan hasil belajar kimia siswa kelas $\mathrm{X}$ Desain Grafika 1 SMK Negeri 4 Gowa.

\section{METODE PENELITIAN}

Penelitian ini adalah penelitian tindakan kelas (classroom action research) dengan tahapantahapan pelaksanaan meliputi perencanaan, pelaksanaan tindakan, 
observasi/evaluasi dan refleksi. Penelitian tindakan kelas ini telah dilaksanakan di SMK Negeri 4 Gowa. Subjek penelitian adalah siswa kelas $\mathrm{X}$ Desain Grafika 1 tahun pelajaran 2018/2019 yang berjumlah 35 orang.

Prosedur Penelitian Tindakan Kelas (PTK) ini dilaksanakan dalam dua siklus. Siklus pertama dilaksanakan sebanyak dua kali pertemuan proses belajar mengajar dan satu kali pertemuan untuk tes dan siklus kedua dilaksanakan sebanyak dua kali pertemuan proses belajar mengajar dan satu kali pertemuan untuk tes.

Data hasil observasi selama proses pelaksanaan pembelajaran berlangsung dianalisis secara kualitatif, data skor rata-rata dari hasil tes tiap siklus dianalisis dengan menggunakan statistik deskriptif, kemudian hasilnya dikelompokan berdasarkan kriteria ketuntasan yang ditetapkan oleh sekolah.

Kriteria ketuntasan belajar klasikal siswa dalam kelas disajikan pada Tabel 1. Indikator keberhasilan dalam penelitian ini adalah meningkatnya hasil belajar siswa atau ketuntasan belajar siswa dari data sebelumnya.
Tabel 1. Kriteria Ketuntasan Belajar Siswa SMK Negeri 4 Gowa

\begin{tabular}{cc}
\hline Nilai & Kategori \\
\hline $75-100$ & Tuntas \\
\hline $0-74$ & Tidak Tuntas \\
\hline
\end{tabular}

\section{HASIL DAN PEMBAHASAN}

A. Aktivitas Belajar

Data mengenai aktivitas siswa diperoleh melalui lembar observasi selama proses belajar mengajar berlangsung selama tiga kali pertemuan, presentase aktivitas siswa tersebut berdasarkan hasil observasi yang dilakukan oleh satu orang observer. Observasi yang dilakukan pada siklus I sama dengan siklus II. Berdasarkan hasil analisis data, menunjukkan terjadinya peningkatan aktifitas belajar dan hasil belajar siswa dari siklus I ke siklus II, dimana pada setiap pertemuan, rata-rata siswa dapat menyelesaikan 5 soal latihan. Hasil analisis kualitatif berdasarkan data hasil observasi tentang keaktifan saat proses belajar mengajar berlangsung mengalami peningkatan. Peningkatan keaktifan siswa tersebut dapat dilihat pada Tabel 2.

Tabel 2. Perbandingan Aktivitas Siswa Pada Siklus I dan Siklus II

\begin{tabular}{llcc}
\hline No & \multicolumn{1}{c}{ Indikator yang diamati } & $\begin{array}{c}\text { Siklus I } \\
(\mathbf{\%})\end{array}$ & $\begin{array}{c}\text { Siklus II } \\
(\mathbf{\%})\end{array}$ \\
\hline 1 & Siswa yang hadir & 96,19 & 97,14 \\
\hline 2 & Siswa yang menyimak penjelasan materi pelajaran & 88,57 & 85,71 \\
\hline 3 & Siswa yang mencatat materi pelajaran & 86,67 & 97,14 \\
\hline 4 & Siswa yang bertanya & 9,52 & 17,14 \\
\hline 5 & Siswa yang menanggapi/menjawab pertanyaan siswa/guru & 6,67 & 12,86 \\
\hline 6 & $\begin{array}{l}\text { Siswa yang aktif mengerjakan latihan secara } \\
\text { individu/berkelompok }\end{array}$ & 68,57 & 95,71 \\
\hline
\end{tabular}




\begin{tabular}{llll}
\hline 7 & Siswa yang meminta bimbingan saat mengerjakan latihan & 16,19 & 15,71 \\
\hline 8 & Siswa yang mengerjakan latihan di papan tulis & 15,24 & 17,96 \\
\hline
\end{tabular}

Peningkatan keaktifan siswa pada Tabel 2 yang paling menonjol adalah siswa yang bertanya, menanggapi atau menjawab pertanyaan, mengerjakan latihan secara berkelompok, dan mengerjakan latihan di papan tulis. Siswa yang bertanya mengalami peningkatan dari $9,52 \%$ menjadi $17,14 \%$, siswa yang menanggapi atau menjawab pertanyaan meningkat dari $6,67 \%$ menjadi $12,86 \%$, siswa yang aktif mengerjakan latihan mengalami peningkatan dari $68,57 \%$ menjadi $895,71 \%$, sedangkan siswa yang mengerjakan latihan di papan tulis mengalami peningkatan dari $15,24 \%$ menjadi $\quad 17,96 \%$. Rata-rata peningkatan keaktifan siswa sesuai dengan indikator yang diobservasi yaitu $8,30 \%$. Adapun siswa yang meminta bimbingan kepada guru saat mengerjakan latihan tidak mengalami peningkatan, hal ini disebabkan karena siswa lebih cenderung untuk meminta bantuan atau bertanya kepada teman kelompoknya.

Refleksi aktivitas belajar pelaksanaan Siklus I yaitu pada pertemuan I, II, dan III, masih dirasakan beberapa kesulitan dalam menghadapi siswa, hal yang paling menonjol adalah masih kurangnya siswa yang bertanya (observasi 4), siswa yang memberi tanggapan atau menjawab pertanyaan (observasi 5), siswa yang mengerjakan latihan secara individu (observasi 6), siswa yang meminta bimbingan serta siswa yang mengerjakan latihan di papan tulis (observasi 7 dan 8). Selanjutnya, aktivitas yang diobservasi selama pelaksanaan tindakan pada siklus II dengan menerapkan pembelajaran drill pada umumnya telah memperlihatkan peningkatan keaktifan siswa dalam proses belajar jika dibandingkan dengan siklus I. Peningkatan keaktifan siswa ini, terjadi dengan adanya beberapa perubahan tindakan pada siklus II sehingga keterlibatan dan keaktifan siswa dalam proses belajar mengajar menjadi lebih baik.

\section{B. Hasil Belajar}

Data hasil belajar kimia pada siklus I diperoleh melalui pemberian tes hasil belajar kimia. Data hasil tes tersebut dianalisis secara deskriptif dan menunjukkan bahwa skor tertinggi yang diperoleh pada siklus I yaitu 80 dan skor terendah yaitu 35 dengan skor rata-rata siswa dalam kelas adalah 54,39 dengan jumlah 35 siswa. Hal ini menujukkan bahwa hasil belajar siswa pada siklus I masih tergolong rendah. Nilai ketuntasan belajar siswa berdasarkan daya serap siswa terhadap materi pelajaran yang dikelompokkan ke dalam kategori tuntas dan tidak tuntas, maka diperoleh distribusi, frekuensi dan persentase belajar kimia yang disajikan pada Tabel 3 . 
Tabel 3. Deskriptif Ketuntasan Belajar Siswa pada Siklus I

\begin{tabular}{cccc}
\hline Kategori & Skor & Frekuensi & Persentase (\%) \\
\hline Tidak Tuntas & $0-74$ & 25 & 71,43 \\
\hline Tuntas & $75-100$ & 10 & 28,57 \\
\hline \multicolumn{2}{c}{ Jumlah } & 35 & 100 \\
\hline
\end{tabular}

Tabel 3 menunjukkan bahwa pada siklus I, hasil belajar kimia siswa kelas X Desain Grafika 1 belum berada pada kategori tuntas sebab banyaknya siswa yang memperoleh nilai $\geq 75$ hanya 10 orang yang apabila dipresentasekan memiliki nilai sebesar $28,57 \%$.

Hasil analisis deskriptif tes hasil belajar kimia siswa pada siklus II memperlihatkan bahwa terjadi peningkatan hasil belajar kimia siwa kelas X Desain Grafika 1. Hal itu dapat dilihat dari meningkatnya skor yang diperoleh siswa pada siklus II dimana skor tertinggi yang diperoleh siswa yaitu 85 dan untuk skor terendah yaitu 40. Selain itu, nilai rata-rata kelas untuk siklus II juga mengalami peningkatan dari 54,39 menjadi 61,05 . Ketuntasan belajar siswa berdasarkan daya serap siswa terhadap materi pelajaran yang dikelompokkan ke dalam kategori tuntas dan tidak tuntas, maka diperoleh distribusi, frekuensi dan persentase belajar kimia yang ditnjukkan pada Tabel 4.

Tabel 4. Deskriptif Ketuntasan Belajar Siswa pada Siklus II

\begin{tabular}{|c|c|c|c|}
\hline Kategori & Skor & Frekuensi & Persentase (\%) \\
\hline Tidak Tuntas & $0-74$ & 8 & 22,85 \\
\hline Tuntas & $75-100$ & 27 & 77,15 \\
\hline \multicolumn{2}{|c|}{ Jumlah } & 35 & 100 \\
\hline
\end{tabular}

Data di atas menunjukkan bahwa pada siklus II, hasil belajar kimia siswa kelas X Desain Grafika 1 sudah berada pada kategori tuntas sesuai dengan standar ketuntasan minimal yang ditetapkan oleh sekolah yaitu $75 \%$, dimana banyaknya siswa yang memperoleh skor $\geq 75$ yaitu 27 orang yang apabila dipersentasekan memiliki nilai $77,15 \%$. Hasil refleksi pada siklus II memperlihatkan bahwa sebagian besar hambatan yang ditemukan pada siklus I dapat teratasi dan tidak terjadi lagi pada siklus II, sehingga dapat dinyatakan bahwa Model pembelajaran Drill memberikan kontribusi yang positif terhadap aktivitas dan hasil belajar kimia siswa kelas X Desain Grafika 1 SMK Negeri 4 Gowa. Perbandingan hasil belajar pada siklus I dan siklus II dapat dilihat pada Tabel 5. 
Tabel 5. Perbandingan Hasil Belajar Siswa Pada Siklus I dan Siklus II

\begin{tabular}{llcc}
\hline No & Kategori & Siklus I (\%) & Siklus II (\%) \\
\hline 1 & Skor tertinggi & 80 & 85 \\
\hline 2 & Skor terendah & 35 & 40 \\
\hline 3 & Skor rata-rata & 54,39 & 61,50 \\
\hline 4 & Tuntas ( skor $\geq 75)$ & 28,57 & 77,15 \\
\hline 5 & Tidak tuntas $($ skor $<75)$ & 71,43 & 22,85 \\
\hline
\end{tabular}

Hasil penelitian pada Tabel 5 menunjukkan bahwa pada siklus I, skor tertinggi yang diperoleh oleh siswa yaitu 80 dan skor terendah adalah 35 dan setelah nilai hasil belajar siswa kelas X Desain Grafika 1 dirataratakan, maka nilai yang diperoleh adalah 54,39. Mengacu kepada standar ketuntasan belajar yang ditetapkan oleh sekolah, maka banyaknya siswa yang masuk kategori tuntas hanya sebanyak 10 orang, sedangkan sisanya 25 orang berada pada kategori tidak tuntas, ini berarti bahwa ketuntasan yang dicapai hanya $28,57 \%$. Kebanyakan siswa pada siklus I, masih kesulitan dalam menentukan molalitas, dimana siswa yang mampu menyelesaikan tes yang berkaitan dengan penentuan molalitas hanya sebanyak 10 orang atau sekitar $38,57 \%$.

Berdasarkan indikator keberhasilan yang ditetapkan dalam penelitian ini, maka dapat dikatakan bahwa penelitian pada siklus I ini belum berhasil. Oleh karena itu, penelitian ini diteruskan ke siklus II dengan meninjau kembali (merefleksi) hal-hal yang harus dibenahi, diperbaiki dan ditingkatkan sehingga hasil belajar dan keaktifan siswa bisa lebih meningkat.
Fokus refleksi yang dilakukan adalah bagaimana mengaktifkan siswa agar lebih memperhatikan pelajaran, lebih berani bertanya atau memberikan tanggapan serta aktif dalam mengerjakan latihan-latihan yang diberikan. Oleh sebab itu, perbaikan yang dilaksanakan pada siklus II lebih ditekankan pada pengelolaan kelas agar proses belajar mengajar dapat berjalan lancar dan lebih aktif. Perbaikan langkah pada siklus II ini meliputi pemberian motivasi, dorongan ataupun penghargaan, sehingga siswa merasa termotivasi dan lebih berani untuk bertanya, menanggapi atau menjawab pertanyaan. Perbaikan langkah yang lainnya adalah membagi siswa dalam kelompok kecil yang beranggotakan 3 orang secara heterogen sehingga siswa yang merasa ragu atau kurang percaya diri untuk bertanya langsung kepada guru dapat bertanya kepada teman dalam kelompoknya dan menunjuk langsung kepada siswa untuk menjawab atau menanggapi pertanyaan serta untuk mengerjakan latihan di papan tulis, sehingga siswa akan selalu berusaha mempersiapkan diri.

Dari hasil analisis deskriptif siklus II memperlihatkan bahwa terjadi peningkatan hasil belajar kimia. Hal 
ini dapat dilihat dari meningkatnya skor yang diperoleh siswa setelah dilakukan tes siklus II dimana skor tertinggi adalah 85 dan skor terendah adalah 40 dan setelah dirata-ratakan menjadi 61,50 (rata-rata kelas). Meskipun peningkatan rata-rata skor hasil belajar siswa tidaklah terlalu signifikan, yaitu dari 54,39 menjadi 61,50 , namun nilai yang mencapai standar ketuntasan hampir merata pada siswa sehingga banyak siswa yang masuk pada kategori tuntas. Mengacu pada standar ketuntasan belajar siswa yang ditetapkan oleh sekolah, dapat dilihat bahwa sebanyak 27 siswa berada pada kategori tuntas dengan persentase $77,15 \%$. Sedangkan jumlah siswa yang masih berada pada kategori tidak tuntas sebanyak 8 siswa yang jika dipersentasekan sebesar 22,85\%.

Berdasarkan hasil penelitian dan uraian di atas, diperoleh informasi bahwa penerapan pembelajaran Drill dapat meningkatkan hasil belajar siswa dengan menggunakan langkah-langkah sebagai berikut:

1. Guru menyampaikan tujuan pembelajaran yang ingin dicapai dan model yang akan digunakan (model drill);

2. Guru memberikan apersepsi kepada siswa;

3. Guru membentuk kelompok yang beranggotakan 3 orang secara heterogen;

4. Guru membahas materi pokok dengan singkat disertai dengan contoh soal dan memberikan kesempatan kepada siswa untuk bertanya;

5. Guru memberikan soal latihan berulang kali (pemberian latihan secara terstruktur), kemudian mengerjakan latihan secara berkelompok;

6. Guru tetap mengawasi dan memberikan bimbingan jika terdapat kesulitan;

7. Guru mengevalusi hasil belajar dengan cara menunjuk beberapa orang untuk mempresentasekan /menuliskan hasil pekerjaan kelompoknya setiap selesai mengerjakan satu soal, 8) guru memberikan penghargaan kepada siswa/kelompok yang mampu menyelesaikan latihan dengan benar.

\section{KESIMPULAN DAN SARAN}

\section{A. Kesimpulan}

Model pembelajaran Drill dapat meningkatkan keaktifan dan hasil belajar siswa kelas $\mathrm{X}$ Desain Grafika 1 SMK Negeri 4 Gowa. Ketuntasan hasil belajar siswa kelas X Desain Grafika 1 SMK Negeri 4 Gowa pada siklus I adalah dan rata-rata hasil belajar kimia Peserta didik pada siklus II adalah $77,15 \%$ dengan ketuntasan belajar $100 \%$.

\section{B. Saran}

Berdasarkan hasil yang diperoleh dalam penelitian ini, maka saran yang dapat dikemukakan oleh penulis adalah hendaknya guru melakukan pembelajaran yang menitikberatkan pada keaktifan siswa, dan salah satu cara yang dapat dilakukan adalah dengan menerapkan model pembelajaran drill. 
Penerapan Model Pembelajaran Drill terhadap Aktivitas dan Hasil Belajar Siswa

Kelas X Desain Grafika I Di SMK Negeri 4 Gowa

\section{DAFTAR PUSTAKA}

Halia. 2008. Peningkatan Hasil Belajar Kimia Melalui Penerapan Metode Latihan Berstruktur pada Siswa Kelas XI IPA 2 SMA N 1 Barru. Jurnal Ilmu Kependidikan, Vol. 5 No. 1, Mei 2008.

Muhibbin Syah. 2004, Psikologi dengan Pendekatan Baru (edisi revisi), PT Remaja Rosda Karya, Bandung.
Ramlah. 2018. Penerapan Metode Pembelajaran Drill terhadap Hasil Belajar Kimia Siswa Kelas X ATPH 1 SMK Negeri 4 Gowa. Jurnal Chemica, Vol 19 No. 1 Juni 2018. 